\title{
Ковнєров О.
}

кандидат філософських наук, доцент кафедри філософії, соціальнополітичних і правових наук Донбаського державного педагогічного університету Муравльова В.

Студентка другого курсу факультетупПсихології, економіки та управління Донбаського державного педагогічного університету

\section{РОЛЬ АКСІОЛОГІї У ФІЛОСОФСЬКО-ПЕДАГОГІЧНІЙ ДУМЦІ}

В статті досліджується виховання сучасного студентства - майбутніх вчителів, на основі загальнолюдських і національних иінностей, яке здатне вирішити одне з складних завдань педагогічної антропології - зберегти людину не тільки як істоту розумну, але і надзвичайно духовну, бо тільки духовність може виступати гарантом подальшого існування людства. Досліджується освіта, яка є могутнім фактором розвитку духовної культури української політичної нації, вона ж може стати дієвим механізмом формування і поширення глобальних иінностей, 
а також сприяти пошуку компромісів між традиційними національними цінностями $і$ изінностями глобальної культури. У ц̧ьому зв'язку концептуальні засади і державні пріоритети розвитку освіти України, відображені у відповідних документах, відображають дві стратегічні мети: забезпечення високої якості освіти і входження в європейський і світовий освітній простір.

Сучасн а українська освіта може $і$ повинна сприяти зняттю динамічного напруження процесів глобалізащії-йдеться про те, щуо сьогодні глобалізація, яка проявлясться в різноманітних стихійних $i$ слабко керованих процесів світової соціокультурної системи, н агадує вулкан, щзо в будь-який момент може здійснити непередбачуваний і небезпечний викид своєї лави.. Саме о сві та здатна ініціювати вибудовування «культурної матриц $i$ глобалізації» $i$ сприяти підкоренню ї̈ норм а м відносної стійкості, смислу $i$ загальнолюдських изінностей, нормам людяності і гуманізму. Зр ештою, сучасна система осві ти поєднує в собі три зовсім різні ціннісні виміри - вимір культури, політики і ринку. Тому, з одного боку, сучасна освіта м аксимально збагачена в цүіннісному відношенні, щзо на дає їй більще можливостей для підтримки глобалізаційних процесів; з іншого ж бокувона сама перенасичена внутрішніми аксіологічними суперечностями.

Ключові слова: освіта, циивілізація, інтелект, світова спільнота, навчання, виховання, гуманізація, аксіологія.

\section{Kovnerov $\mathbf{O}$.}

Phd in Philosophy, Associate Professor of Philosophy, socio-political and law sciences department of Donbas state pedagogical university

Muravlova V.

Student of the Faculty of Psychology, Economics and Management

Donbas State Pedagogical University

\section{THE ROLE OF AXIOLOGY IN PHILOSOPHICAL AND PEDAGOGICAL IDEA}

The article explores education of modern students - future teachers, based on universal and national values, which is capable of solving one of the difficult tasks of pedagogical anthropology - to preserve a person not only as being intelligent, but also extremely spiritual, because only spirituality can act as the guarantor of the further existence of mankind. Education, which is a powerful factor in the development of the spiritual culture of the Ukrainian political nation, can also become an effective mechanism for the formation and spread of global values, as well as to promote the search for compromises between traditional national values and the values of global culture. In this regard, the conceptual framework and state priorities for the development of education in Ukraine, reflected in the relevant documents, reflect two strategic objectives: ensuring high quality education and entry into the European and world educational space.

Modern Ukrainian education can and should contribute to the removal of the dynamic tension of globalization processes - it is said that today globalization, which manifests itself in the various spontaneous and weakly controlled processes of the 
world socio-cultural system, resembles a volcano that can at any moment carry out an unpredictable and dangerous emission of its own lava. It is education that is capable of initiating the construction of the "cultural matrix of globalization" and contributing to its compliance with the norms of relative stability, meaning and universal values, norms of humanity and humanism. In the end, the modern educational system combines three totally different values - the measurement of culture, politics and the market. Therefore, on the one hand, modern education is maximally enriched in value, which gives it more opportunities to support globalization processes; on the other hand - she is saturated with internal axiological contradictions.

Key words: education, civilization, intellect, world community, education, education, humanization, aceology.

\section{Ковнеров А.}

кандидат философских наук, доцент кафедры философии, социальнополитических и правовых наук

Донбасского государственного педагогического университета

\section{Муравлева В.}

Студентка второго курса факультета Псисихологии, экономики и управления Донбасского государственного педагогического университета

\section{РОЛЬ АКСИОЛОГИИ В ФИЛОСОФСКО-ПЕДАГОГИЧЕСКОЙ МЫСЛИ}

В статье исследуется воспитание современного студенчества - будущих учителей на основе общечеловеческих и национальных цуенностей, которое способно решить одну из сложнейших задач педагогической антропологии - сохранить человека не только как существо разумное, но и чрезвычайно духовное, так как, только духовность может выступать гарантом дальнейшего существования человечества. Исследуется образование, которое является мощуным фактором развития духовной культуры украинской политической нации, оно же может стать действенным механизмом формирования и распространения глобальных иенностей, a также способствовать поиску компромиссов между традиционными национальными ценностями и ценностями глобальной культуры. В связи с этим, кониептуальные основы и государственные приоритеты развития образования Украины отражены в соответствуюших документах, отображающих две стратегические чели: обеспечение высокого качества образования и вхождения в европейское и мировое образовательное пространство.

Современное украинское образование может и должно способствовать снятию динамического напряжения процессов глобализации - говорится о том, что сегодня глобализация, которая проявляется в различных стихийных и слабо управляемых процессах мировой сочииокльтурной системы, напоминает вулкан, что в любой момент может осуществить непредсказуемый и опасный выброс. Именно образование способно инициировать выстрачвание «культурной матрицы глобализацииџ и способствовать подчинению ее нормам относительной устойчивости, смысла и общечеловеческих цүенностей, нормам 
человечности и гуманизма. В кони е конщов, современная система образования сочетает в себе три совершенно разные ценностны е измерения - измерение культуры, политики и рынка. Поэтому, с одной стороны, современное образование максимально обогащенно в и енностном отномении, что придает ему больше возможностей для поддержки глобализаџионных прочессов; с другой же стороны - оно само перенасыщено внутренними аксиологическими противоречиями.

Ключевые слова: образование, циивилизация, интеллект, мировое сообщество, обучение, воспитание, гуманизация, аксеология.

Постановка проблеми: Розбудова єдиного Свропейського Дому безпосередньо залежить від стратегічного ресурсу розвитку цивілізації - інтелекту - науки, культури і освіти, навчання і виховання нових поколінь, розвиток яких розглядається нині як одне 3 найбільш актуальних питань життєствердження європейської, а слідом за нею - і світової спільноти.

Потужний інтелект, розгалужена наука і якісна о світа є саме тими умовами, за якими уже розпочали цивілізаці йні перегони провідні д ержави світу. Свідченням тому є Болонський процес, що об'єднує всіх суб'єктів європейського освітнього простору формуванням єдиних правил о світньо-наукової і виховної діяльності, нормами поведінки як на державному, так і на побутовому рівнях.

Звернення до даної теми зумовлено поширенням явища аномії в українському сусп ільстві. У т акій ситуації на вчителя н акладається відповідальність 3 а збереження і трансляцію засобами освіти іiі ціннісного потенціалу, що, в свою чергу, передб ачає перегляд аксіологічних пріоритетів педагогічної підготовки, їх кореляцію з модернізаці йними освітніми завданнями. Професія вчителя $є$ не тільки унікальною, але й виключно людською. Вона сформувалась як відповідь на потребу систематизованої перед ачі знань, практичного досвіду й цінностей від одного покоління до і ншого, виховання особистост і в дусі ті єї системи норм i правил, які прийняті в даній людській спільноті - у племені, в народі, нації, державі чи суспільстві загалом.

Стає оче видним, що дослідження проблем підготовки сучасного вчителя $\epsilon$ авангардним, оскільки з цим процесом зв'язується оптимальний розвиток особистості, майбутнє людини і людства. Від рівня розвитку професійно значущих якостей педагога залежить не тільки соціально -етичне здоров'я країни, але і щастя окремо взятої людини. Тому так важливо з'ясувати фі лософсько-освітні резерви в підготовці педагога. Основними напрямами цього процесу $є$ виявлення і зважена оцінка цінн існих пріорит етів сучасного педагога, моделювання ціннісної системи освіти з урахуванням вимог третього тисячоліття як століття людини і розвиток аксіосфери вчителя як духовного центру соціуму.

Проблема професійно-педагогічних ціннісних орієнтацій в основному до сліджується на рівні визначення і аналізу спектру ці нностей сучасного вчителя, їх порівняльної характеристики з представниками других професій, спроб класифіка ції ціннісних орієнтац ій педагога. Питання, пов'язані з визначенням феномена ціннісних орієнтацій в педагогічній площині, шляхів і засобів їх 
цілеспрямованого розвитку у майбутнього вчителя, розглядалися недостатньо, що, ймові рно, пов’язано зі складністю, міжди сциплінарністю, поліфункціональністю, динамізмом самого явища ціннісних орієнтаці й. Певні складнощі викликає і специфіка аксіологічних засобів. Це пояснюється нед етермінованістю причинно- наслідкових зв'язків і достатньо варіативно-явним (стохастичним) розвитком ціннісних орієнтац ій. У зв'язку з цим положенням стає очевидним, що формаліза ція змісту освіти в системі вищої освіти з погляду чі тко визначених ціннісних орієнтацій неможлива. Необхідність по силення аксіологічної підготовки майбутнього вчителя є одним з пріоритетних напрямків модернізації вищої педагогічної освіти. Власне така дослідницька позиція й зумовила вибір теми дисертації та ії структуру.

Виклад основного матеріалу. Фі ло софія о світи, звертаючись до аксіологі чної проблематики, спирається на ті загальні теоретико-методологічні підходи , що вироблені в аксіології як філософській теорії цінностей . Тому основні парадигмальні побудови філософсько-педагог ічної аксіологї в тій частині, яка стосується розуміння питання про природу цінност ей, сполучення об'єктивного i суб'єктивного в них, взаємозв'язок цінностей із соціальними і культурними чинниками, про механізми їхнього виникнення і функціонування, співвідносні 3 основними парадигмальними побудовами аксіології загалом.

У забезпеченні гуманістичної спрямованості професійної діяльності педагога та його ціннісних орієнтацій вказував практично кожен дослідник, який торкався цієї тематики, чи розгортав їі під час реконструкції власної педагогічної системи.

Значний доробок у цьому плані презентований західною філософською та культурологічною думкою, зокрема, працями М.Вебера, А.Вебера, В.Віндельбанда, М.Гартмана, Г.Рікерта, В.Дільтея, Р.Кронера, Е.Кассірера, Е.Гусерля, Г.Зіммеля, А.Швейцера, О.Шпеглера, А.Тойнбі, К.Ясперса та ін.

Мета статті полягає у експлікації педагогічної аксіології як одного 3 методологічних орієнтирів модернізації професійно-педагогічної освіти.

Професійно-педагогічні орієнтації українського вчительства - це унікальне явище по духовній глибині, емоційній насиченості і альтруїстичній готовності «віддати себе дітям», це тезаурус, наповнений етичними заповідями, скарбами думки, поведінковими моделями. Для того, щоб проаналізувати ціннісні орієнтації української освіти, треба використовувати будь-яке прагнення, будь-який почин, будь-яку можливість актуального прочитання педагогічної спадщини класиків вітчизняної педагогіки, бо ця спадщина володіє універсальним духовним потенціалом, який може і повинен служити джерелом розробки і впровадження освіти, що гарантує розвиток у молоді сприйняття неревізійних духовно-етичних цінностей, розбірливості в відношенні до ціннісних новоутворень, що породжуються сучасною ситуацією.

Без сумніву, вчитель в українській школі - це центральна фігура педагогічного процесу. Ця теза має підтвердження в численних роботах К.Ушинського, присвячених «ратоборцю істини i добра», «надії і славі», національному вчителеві. Подібно до інших складних явищ, на думку К.Ушинського, педагогічна діяльність володіє безліччю властивостей, якостей, 
рис, сторін, функцій , зв'язків, що виявляють ії аксіологічну природу і поліфон ічність проявів в освітній сфері. Виходячи з цього, спробуємо розглянути основні аксіологічні характеристики педагогічної діяльності вчителя української школи.

К.Ушинський в основу роботи вчителя поставив антропологічний принцип, що передбачає визнання цілісно сті людини , органічної єдно ст і в нім духовної і тілесної природи. Ця обставина зн аходить своє вираження в тому, що вищою цінністю в педагогічному процесі $є$ людина, а для вчителя першорядне значення має уміння осягнути людську природу, навчитися управляти нею на благо самої людини і народу в цілому.

Поза сумнівом, що найважливішим аксіологічним орієнтиром педагогічної діяльності є вивчення особистості п ідростаючої людини. Причому , як стверджує К.Ушинський, вихователь повин ен пр агнути ді зн атися людину, якою вона $\epsilon$ насправді, зі всіма іiі слабостями і у всій ії величі, зі всіма іiі буд енними, дрібними потреб ами і зі всіма ії великими духовними вимогами (5, с. 367). Безумовно, тільки та кий підхід до об'єкту діяльност і вчителя дозволить доцільно вирішувати завдання о світнього процесу i, на думку К.Ушинського , черпати величезні засоби виховного впливу в самій природі людини. Природно, що глибоке і усестороннє вивчення природи людини перетворює педагогічну діяльність в інструмент дбайливого дотику, філігранної обробки особистості кожного вихованця.

Проте для вирішення таких відповідальних завдань педагогічна діяльність повинна бути психологічною, оскільки вчитель постійно обертається в області психологічних явищ: вивчає здібності і схильності вихованців, помічає розвиток розуму, діє на волю, розкриває розум і т. д. Педагог може не бути глибоким психологом, ал е все-таки саме для цієї професі ї властиве вивчення психічної сфери людини, саме для неї надзвичайно важливі знання психології особистості, суті людської природи, що веде до осягнення, і її цілеспрямованої зміни.

Важливою хар актеристикою педагогі чної діяльності $є$ відчуття сучасності, уміння відчувати і реалізовувати вимоги часу. К.Ушинський стверджував, що «глухота» педагога до законних вимог часу веде до втрати школою життєвої сили. Несучасність вчителя не дозволяє йому викон ати свій громадянський i професійний обов'язок, а, на йголовніше, такий вчитель «довіряє» «довиховувати» учнів життям зі всі ма його складнощами і непередбачуваністю. Зрозуміло, що відчуття сучасно сті вчителя актуально для сьогоднішньої школи, оскільки від рівня шкільного виховання, залучення учн ів до цінностей на ціонального і загальнолюдського масштабу можна перейти до «довиховування» суспільством, задавши йому сучасний цивілізований ритм життя. Підтверджуючи це, К.Ушинський відзн ачав: «Вихователь, що стоїть в рівень з сучасним ходом виховання, відчуває себе живим, діючим членом великого організму, що бореться з неуцтвом і пороками людства, посередником між всім, що було благородного і високого в минулій історії людей, і поколінням новим, хранителем святих заповідей людей, що боролися за істину і за благо. Він відчуває себе живою ланкою між минулим і майбутнім, могутнім ратоборцем істини і добра, і усвідомлює, що його справа, скромна - одна з найбільших справ в історії, що на 
цій справі грунтуються царства і нею живуть ц ілі покоління $(136$, с. 32)». Зрозуміло, що при цьому вчитель повинен бути не просто сучасним, і не тільки уміти зб ерігати традиції і заглядати в майбутнє. Вчитель повинен бути народним. Останнє визначення $€$ ключе м до розуміння специфіки української школи. Дійсно, в українські й школі, н а думку К.Ушинського, повинні працювати народні вчителі, які вийшли 3 народу і несуть з собою його кр ащі, характерні властивості, які намагаються відтворити народний iдеал людини в окремих особистостях $(6$, с. 487$)$.

Приваблива і така характеристика вихователя, як його переконаність. Діяльн ість, забарвлена світлом переконаності, м ає величезну силу в справі дії на розум, душу, волю вихованця. «Найголовніша дорога людського виховання $\epsilon$ переконання, а на переконання можна діяти тільки переконанням. Всяка прогр ама викладання, всяка методика виховання, яка б хороша вона не була, що не перейшла в переконання вихователя, залишиться мертвою буквою, що не має ніякої сили насправді (6, с. 28)». Сила виховання, н а думку К.Ушинського, полягає в тому, що будь-які дії вчителя «зігріваються» теплом його о собистого переконання, будь-яка інструкція набуває актуального звучання в площині переконаності вихователя.

Величезне значення у висловах К.Ушинського має духовно-етичний потенціал педагогічної діяльності. «Ми сміливо висловлюємо переконання, що вплив етичний складає головне завдання виховання, набагато важливіший, ніж розвиток розуму взагалі, наповнення пізнаннями (6, с. 431)». Етичні характеристики властиві і відносинам педагога з вихованцями. Вони будуються на основі аксіологічних категорій гуманістичної етики: любові, добра, віри, терпіння, дружби, справедливості. К.Ушинський вважав головними ціннісними орієнтаціями в діяльності вчителя - виховання в учнів любові до Батьківщини, до свого народу і його історичного минулого, формування їх духовності на кращих традиціях народної культури, засобами рідної мови, народної творчості, вітчизняної історії і географії.

Торкнувшись питання про етичну характеристику діяльност і вчителя, не можна н е пригадати про застереження великого педагога відносно проводження вільного часу вихованцями, «коли людина залишається без роботи в руках, б ез думки в голові», «саме в ці хвилини псується голова, серце і моральність (6, с. 359)». У подібному твердженні є серйозне попередження і сучасній школі, можливості якої в організації життя школярів не реалізуються повною мірою.

Разом $з$ тим важливо підкреслити аксіологі чне значення для п едагогічної діяльності посилання на наукові знання в області анатомії, фізі ології, психології, логіки, економіки і т. д., генетичний зв'язок теорії і практики в роботі вчителя. Цьому К.Ушинський надавав особливе знач ення, оскільки вчитель може в педагогічній і іншій спеціальній лі тературі почерпнути унікальні ідеї для втілення на практиці, вийти за межі свого до свіду, а практика $є$ живильним середовищем для теоретиків, перевіряючих життєздатність педагогічних концепцій. 
В своїх роботах К.Ушинський наголошує і на антицінностях, які не сприяють плідній педагогічній діяльності. До них він відносить «жадання грошей, невіру в добро, відсутність етичних правил, презирство до думки, любов до обхідних стежин, байдужість до суспільного блага, поблажливість до порушення законів честі $(6$, с. 22)».

Розуміння природи педагогічної діяльності, уважне відношення до роботи вчителя в цілому навряд чи співвідноситься з проявом названих антицінностей. А аналіз аксіологічних характеристик діяльності вчителя школи в працях К.Ушинського дозволяє виділити головні цінності - духовні (етичні, політичні, екзистенціальні) i пріоритетність особистості як головного аксіологічного орієнтиру. Це дає підставу назвати педагогіку мистецтвом, що підкреслює творчий характер педагогічної діяльності і необхідність постійного вдосконалення особистісних i професійних якостей вчителя. Привабливість аксіологічних характеристик педагогічної діяльності вчителя зв'язана і з тим, що це народний вчитель, національний по суті, гуманний по відношенню до своїх вихованців.

На вчителя покладається почесний і відповідальний обов'язок - передавати духовну естафету кращих народних традицій і історичних звершень народу. Вчитель, в трактуванні К.Ушинського, це особистість 3 високим відчуттям цивільної відповідальності за благородну місію виховання підростаючого покоління, людина переконана, яскрава, емоційна. Образ вчителя, про якого говорив великий педагог, відображає кращі етичні якості особистості, високий рівень культури.

Якщо ж звернутися до виховання, здатного підтримувати культуру, історію, то в основі його, стверджує вчений, повинно знаходитися щось абсолютне, єдино цінне для особистості, що, або серцем, або свідомістю, відчувається людиною. Для того, щоб досягти таких висот, в основу системи освіти, як стверджує В.Розанов, повинні бути покладені три принципи, реалізація яких, крім усього іншого дозволяє сподіватися на розвиток вихованця.

По-перше, принцип індивідуальності, орієнтуючий на збереження як у вчителеві, так і в учневі ї дорогоцінного надбання, кращого, що має кожен, особливого - індивідуальності, за рахунок чого і здійснюється освіта.

По-друг е, принцип цілості, що вимагає дотримання положення: уникати розірваності в знаннях, в художніх відчуттях. Не слід пер еривати вх ідне в душу враження, відчуття іншим, поки перше не упровадило ся. В.Розанов вважав, що потрі бне вдумливе відношення до всього , «щоб воно ст ало н ам дорогим, щоб воно оволоділо нами після того, як ми ним оволоділи $(2$, с. 97$) »$.

I, по-третє, принцип єдності типу, який має н а увазі, що отримувані вихованцем враження повинні виходити з джерела одної історичної культури.

Пер ераховані принципи, без сумніву, здатні бути фундаментальною основою системи освіти, як а має «скарб », необхідний для вихованців, «свічку», при якій кожен може краще «розглянути своє майно і розібратися в нім (1, с. 215)».

Представники різних філо софських шкіл (н еокантиніа нці натурфілософи, екзистенціалісти, феноменологи та ін.) по різному визначали феномен цінностей, 
проте всіх їх об'єднувала позиція, пов'язана 3 емоційно -плотським базисом цінностей, обгрунтуванням за допомогою аксіологічного підходу цілісності духовного життя.

Нам імпонує точка зору представникі в феноменологічної аксіології про те, що особистість є стрижн ем, центральним ядром «царства цінност ей». Самі ж цінності без усвідомлення їх особистістю не мають ніякого значення.

Ще один висновок філософі в предс тавляєть ся так само дуже важливим цінності зд атні допомогти людині пі знати себе і в цьому пізнанні стати вільною і гуманною. Ймовірно, тому ціннісна система завжди знаходилася на стику етики, естетики, логіки.

Одним 3 найбільш поширених підходів філософів до визначення категорії «цінність» є зацікавлене відношення до світу, направленість суб'єкта на об'єкт.

Унікальним слід рахувати погляд на цінності російських релігійних філософів. Вони переконані, що духовність - це поєднання загальнолюдських i національних цінностей, що людина духовна - це людина, що володіє цінностями, отже, цінності - це втілення духовності.

На наш погляд, слід виділити і ідею вітчизняних філософів ХХ століття; цінності - це відношення людини до самої себе, до навколишніх людей, суспільства. Серед вітчизняних філософів XX століття існує думка про те, що ціннісні відносини є початковим, первинним відношенням до світу, що визначає решту всіх відносин.

\section{Література}

1. Абросимова 3.Ф. Педагогическая культура учителя: учебное пособие для учителей. Курган, 1999. - 68 с.

2. Асташова Н.А. Аксиологическое образование современного учителя. Москва, 2000. $320 \mathrm{c}$.

3. Мудрик Л.В. Общение как фактор воспитания школьников. Москва: Педагогика, 1984. 112 с.

4. Франкл В. Человек в поисках смысла. Москва: Прогресс, 1990. 366 с.

5. Фромм Э. Здоровое общество. Психоанализ и культура. Москва: Юрист, 1995. С. 273-596.

\section{REFERENCES:}

1. Abrosymova Z.F. Pedahohycheskaia kultura uchytelia: uchebnoe posobydlia uchytelei. Kurhan, 1999. - 68 s.

2. Astashova N.A. Aksyolohycheskoe obrazovanye sovremennoho uchytelia. Moskva, 2000. $320 \mathrm{~s}$.

3. Mudryk L.V. Obshchenye kak faktor vospytanyia shkolnykov. Moskva: Pedahohyka, 1984. 112 s.

4. Frankl V. Chelovek v poyskakh smыsla. Moskva: Prohress, 1990. 366 s. 
5. Fromm Э. Zdorovoe obshchestvo. Psykhoanalyz y kultura. Moskva: Yuryst, 1995. S. 273-596.

Надійшла до редакції 05.11.2018 